\title{
Detection of Seed Borne Fungi of Blonde Psyllium by Standard Blotter Methods
}

\author{
Sajjan Choudhary $^{1 *}$, R.P. Ghasolia ${ }^{1}$, A.L. Yadav $^{1}$, G.L. Kakraliya ${ }^{1}$ and R. Nasanwa ${ }^{2}$ \\ ${ }^{1}$ Department of Plant Pathology, S.K.N. College of Agriculture, Jobner 303329 (Jaipur), India \\ ${ }^{2}$ Department of Plant Pathology, C.O.A., Bikaner, Rajasthan, India \\ *Corresponding author
}

\begin{tabular}{|c|c|}
\hline & A B S T R A C T \\
\hline \multicolumn{2}{|l|}{ Keywords } \\
\hline $\begin{array}{l}\text { Alternaria } \\
\text { alternata, } \\
\text { Standard bloter } \\
\text { technique, Potato } \\
\text { dextrose method } \\
\text { and Plantago } \\
\text { ovate, Isabgol. }\end{array}$ & \multirow{4}{*}{$\begin{array}{l}\text { The experiments were conducted at Department of Plant Pathology, S.K.N. } \\
\text { College of Agriculture, Jobner (Rajasthan). Five samples of blonde } \\
\text { psyllium seeds were collected from Barmer, Nagaur, Pali, Jodhpur and } \\
\text { Jalore districts of Rajasthan and tested for seed borne fungi. Both Blotter } \\
\text { and Agar Plate methods were used to detect the maximum number of } \\
\text { mcontrol and external seed borne fungi. A total of } 5 \text { species of fungi were } \\
\text { identified using the two selective methods. The pathogencity of A. alternata } \\
\text { was studied on psyllium seeds and seedlings. }\end{array}$} \\
\hline Article Info & \\
\hline $\begin{array}{l}\text { Accepted: } \\
\text { 29 June } 2017\end{array}$ & \\
\hline $\begin{array}{l}\text { Available Online: } \\
10 \text { July } 2017\end{array}$ & \\
\hline
\end{tabular}

\section{Introduction}

Blond psyllium (Plantago ovata Forsk.) commonly known as isabgol, is an annual herb with narrow linear rosette like leaves belonging to the family Plantaginaceae. Isabgol is an important cash crop cultivated for its export and being of important medicinal value is reported to have larger demands and is traded in major medicinal markets of the world. Isabgol has pharmaceutical importance to treat dysentery, chronic constipation and chronic diarrhoea and as laxative demulcents, emollients and diuretics. India commands nearly monopoly in the production and export of the seed and husk to the world market. India is earning about Rs. 1600 million as foreign exchange from the export of blond psyllium products to countries like USA, Germany, France, England, Spain and Belgium [1].

In India, the isabgol crop is mainly grown as commercial crop in Gujarat, Rajasthan and Madhya Pradesh. However, the crop is spreading to other non-traditional parts of the country such as Haryana, Uttar Pradesh and Karnataka. In Rajasthan, it is being cultivated in 190081 hectares area with a total production of 99950 tonnes of seeds with an average productivity of $525 \mathrm{~kg} / \mathrm{ha}$ [2]. In Rajasthan, lsabgol mainly cultivated in Barmer, Jalore, Nagaur, Jodhpur and Jaisalmer districts. Presently, Rajasthan is on 
the top in productivity in India [3] reported a number of pathogens viz., Fusarium wilt (Fusarium oxysporum), damping off (Pythium ultimum trow), leaf blight (Alternaria alternata (Fr.) Keissler), downy mildews (Peronospora plantaginis) and powdery mildew (Erysiphe cichoracearum D.C.) affecting this crop. Alternaria blight has become a serious problem in recent years. It has been found that downy mildew affected crop is more prone to be attacked by $A$. alternata.

It causes considerable damage every year and sometimes become very severe which results in total loss of yield [4]. Hence, present investigations were carried out to test the efficacy of plant extracts and fungicides against leaf blight of isabgol incited by $A$. alternata.

\section{Materials and Methods}

\section{Collection of seed samples}

To study the seed borne fungi, seed samples were collected from Barmer, Nagaur, Pali, Jodhpur and Jalore districts of Rajasthan. These samples were collected from farmers, where isabgol is generally cultivated.

From each district, 5 samples were collected from farmer's houses belonging to different villages situated 5-10 km away from district headquarter in different geographical directions where isabgol is generally cultivated and stored by using old traditional practices, under variable environmental conditions. At each district headquarter; all collected seed samples were mixed to represent a composite sample of that particular district. Samples were collected 4-6 weeks before sowing in cloth bags, brought to the laboratory and then stored at $10 \pm 1{ }^{\circ} \mathrm{C}$ temperature for further studies.
In all, 5 working samples were analyzed by different procedures suggested by $[5,6,7]$.

\section{Isolation of mycoflora associated with isabgol seeds}

Five seed samples i.e. IG-1, IG-2, IG-3, IG-4 and IG-5 were used separately for the isolation of mycoflora from the isabgol seeds. Two incubation methods viz., (a) Standard Blotter Method and (b) Agar Plate Method [5] were employed for this purpose.

\section{Standard blotter method}

Four hundred seeds from each sample were analyzed after surface sterilization and unsterilization. Blotter papers were cut into 9 $\mathrm{cm}$ diameter circle and sterilized at $1.045 \mathrm{~kg}$ sq $\mathrm{cm}$ for 20 minutes.

Three circles of blotter paper were placed at the bottom of each sterilized Petri plate aseptically and moistened by sterile distilled water. Twenty five seeds were placed at equal distance in each Petri plate.

For sterilized condition, seeds were treated with $0.1 \%$ mercuric chloride $\left(\mathrm{HgCl}_{2}\right)$ solution for one minute and rotated continuously to avoid clumping followed by three washing with sterile distilled water, were used.

These Petri plates were incubated at $25 \pm 1{ }^{0} \mathrm{C}$ for $12 \mathrm{~h}$ of light alternating period. The seeds were examined on $8^{\text {th }}$ day of incubation for the presence of seed borne fungi.

\section{Standard agar plate method}

Two hundred seeds of each of the 5 samples were analyzed after surface sterilization with 0.1 per cent mercuric chloride solution for one minute, followed by 3 washings with sterile distilled water. 
Twenty five seeds were equispaced aseptically per Petri plate $(9 \mathrm{~cm}$ diameter) containing $20 \mathrm{ml}$ of PDA $(250 \mathrm{ppm}$ streptomycin was added to PDA just before pouring into the Petri plates to check bacterial contamination).

The plates were incubated at $25 \pm 1{ }^{0} \mathrm{C}$ for 12 $\mathrm{h}$ of light alternating with $12 \mathrm{~h}$ of dark period. The fungal colonies emanating from seeds were examined from $4^{\text {th }}$ to $7^{\text {th }}$ days of incubation.

Isolation of mycoflora from isabgol seeds were carried out and maintained on 2 per cent PDA medium. Observations on per cent incidence of seed mycoflora were recorded in both Blotter and Agar Plate Methods.

Per cent incidence of fungus (PIF) was calculated as follows:

$$
\text { PIF }=\frac{\text { Number of seeds sowing fungal growth }}{\text { Total number of seeds incubated }}
$$

\section{Results and Discussion}

\section{Isolation of mycoflora associated with isabgol seeds}

\section{Standard blotter method}

Five fungal species belong to four genera in addition to un-identified mycoflora were isolated from sterilized and un-sterilized isabgol seeds (Table 4.1 and Fig. 1). Fungi and their respective per cent incidence from sterilized and un-sterilized seeds were Alternaria alternata (1.00-11.25), Aspergillus niger (1.50-8.25), Curvularia clavata (0.253.75), C. fallax (0.00-2.50), Fusarium semitectum (1.50-7.25) and un-identified mycoflora (0.00-6.25). Per cent incidence of Alternaria alternata, out of total per cent mycoflora was recorded maximum in unsterilized seeds of Jalore sample (29.41) followed by Barmer (27.02), Jodhpur (25.80) and Pali (22.54) while it was minimum in Nagaur sample (21.50).

Per cent incidence of Alternaria alternata including other fungi was less in sterilized seeds as compared to un-sterilized seeds.

The sterilized and un-sterilized seeds were plated on moist blotter paper in sterilized Petri plates for detection of fungal flora.

The total frequency of mycoflora was observed maximum in unsterilized seeds of sample of Jalore $(38.50 \%)$ followed by Pali (25.70\%), Barmer $(18.50 \%)$ and Jodhpur $(15.50 \%)$ and it was minimum in Nagaur $(12.75 \%)$, whereas, in surface sterilized seeds, the incidence of mycoflora was maximum in the sample of Jalore (11.25\%) followed by Pali $(9.25 \%)$ and Barmer $(7.25 \%)$ and it was minimum in samples of Jodhpur $(6.00 \%)$ and Nagaur $(6.00 \%)$.

\section{Standard agar plate method}

Five fungal species belong to four genera in addition to un-identified mycoflora were isolated from isabgol seeds (Table 2 and Fig. 2)). Fungi and their per cent occurrence recorded were Alternaria alternata (1.505.00), Aspergillus niger (2.00-4.50), Curvularia clavata (0.50-2.50), C. fallax (0.00-2.50) and Fusarium semitectum (2.00$3.50)$.

Total per cent mycoflora was maximum in Jalore sample (19.00\%) followed by Pali (13.00\%), Nagaur (12.00\%), Barmer $(12.00 \%)$ and Jodhpur (9.00\%).

Per cent incidence of Alternaria alternata, out of total per cent mycoflora was highest in Jalore (27.77\%) followed by Barmer (25.00\%), Pali (21.15\%), Nagaur (20.83\%) and Jodhpur (16.86\%). 


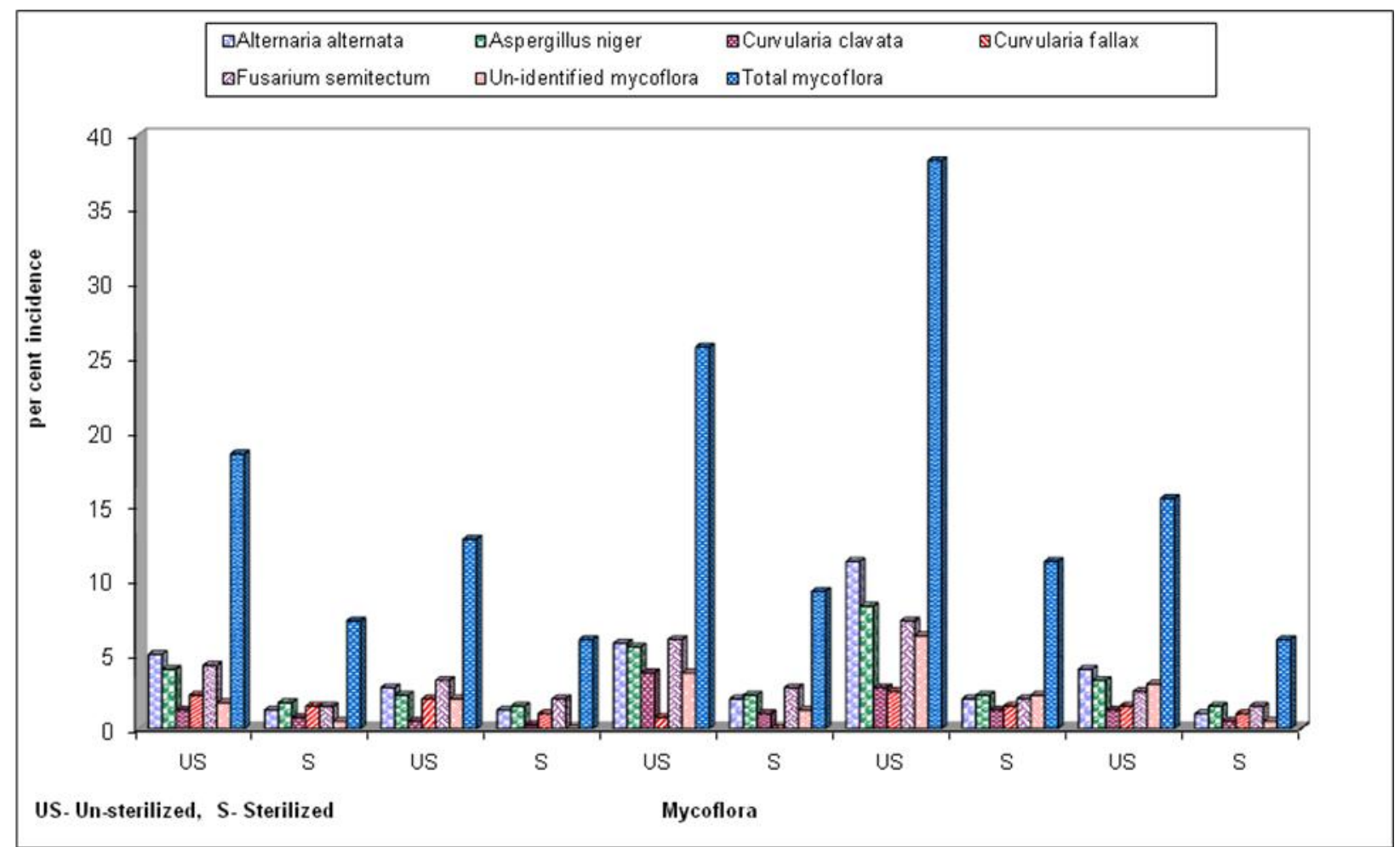

Fig. 1 Incidence of mycoflora associated with isabgol seeds analysed by Standard Blotter Method

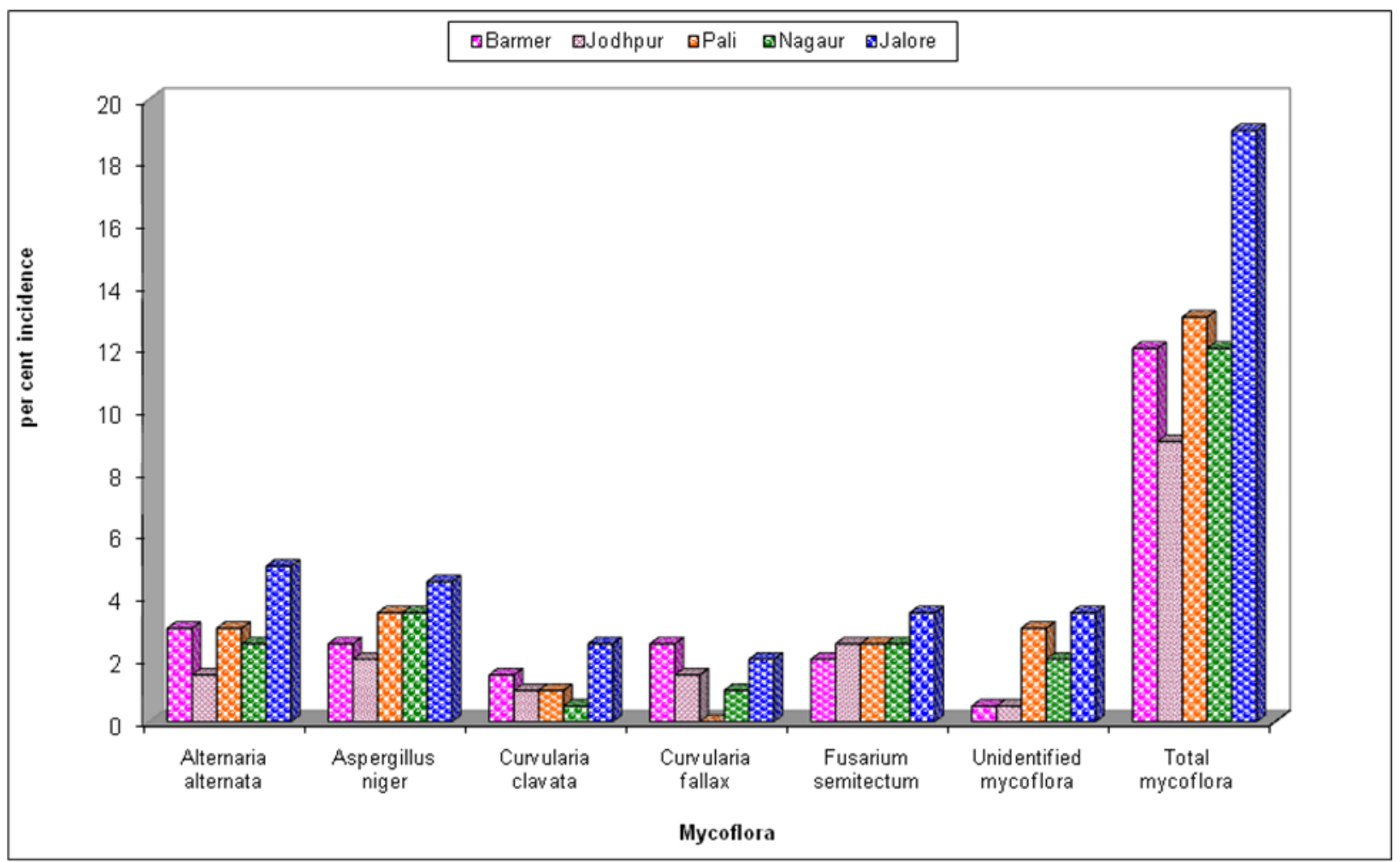

Fig. 2 Incidence of mycoflora associated with isabgol seeds analysed by Standard A gar Plate Method 
Table.1 Incidence of mycoflora associated with isabgol seeds analysed by Standard Blotter Method

\begin{tabular}{lcccccccccc}
\hline \multirow{2}{*}{ Mycoflora } & \multicolumn{10}{c}{ Per cent incidence / sample* } \\
\cline { 2 - 11 } & \multicolumn{2}{c}{ Barmer } & \multicolumn{1}{c}{ Nagaur } & \multicolumn{3}{c}{ Pali } & \multicolumn{2}{c}{ Jalore } & \multicolumn{2}{c}{ Jodhpur } \\
\cline { 2 - 11 } & US & S & US & S & US & S & US & S & US & S \\
\hline Alternaria alternata & 5.00 & 1.25 & 2.75 & 1.25 & 5.75 & 2.00 & 11.25 & 2.00 & 4.00 & 1.00 \\
Aspergillus niger & 4.00 & 1.75 & 2.25 & 1.50 & 5.50 & 2.25 & 8.25 & 2.25 & 3.25 & 1.50 \\
Curvularia clavata & 1.25 & 0.75 & 0.50 & 0.25 & 3.75 & 1.00 & 2.75 & 1.25 & 1.25 & 0.50 \\
Curvularia fallax & 2.25 & 1.50 & 2.00 & 1.00 & 0.75 & 0.00 & 2.50 & 1.50 & 1.50 & 1.00 \\
$\begin{array}{l}\text { Fusarium } \\
\text { semitectum }\end{array}$ & 4.25 & 1.50 & 3.25 & 2.00 & 6.00 & 2.75 & 7.25 & 2.00 & 2.50 & 1.50 \\
Unidentified & & & & & & & & & & \\
mycoflora & 1.75 & 0.50 & 2.00 & 0.00 & 3.75 & 1.25 & 6.25 & 2.25 & 3.00 & 0.50 \\
\hline Total mycoflora & 18.50 & 7.25 & 12.75 & 6.00 & 25.70 & 9.25 & 38.25 & 11.25 & 15.50 & 6.00 \\
Alternaria alternata & 27.02 & 17.24 & 21.56 & 20.83 & 22.54 & 21.62 & 29.41 & 17.77 & 25.80 & 16.66 \\
\hline
\end{tabular}

* Seed tested 400/ sample, US- Un-sterilized, S- Sterilized

Table.2 Incidence of mycoflora associated with isabgol seeds analysed by standard Agar Plate Method

\begin{tabular}{lccccc}
\hline Mycoflora & \multicolumn{4}{c}{ Per cent incidence / sample* } \\
\cline { 2 - 6 } & Barmer & Jodhpur & Pali & Nagaur & Jalore \\
\hline Alternaria alternata & 3.00 & 1.50 & 3.00 & 2.50 & 5.00 \\
Aspergillus niger & 2.50 & 2.00 & 3.50 & 3.50 & 4.50 \\
Curvularia clavata & 1.50 & 1.00 & 1.00 & 0.50 & 2.50 \\
Curvularia fallax & 2.50 & 1.50 & 0.00 & 1.00 & 2.00 \\
Fusarium semitectum & 2.00 & 2.50 & 2.50 & 2.50 & 3.50 \\
Unidentified mycoflora & 0.50 & 0.50 & 3.00 & 2.00 & 3.50 \\
Total mycoflora & 12.00 & 9.00 & 13.00 & 12.00 & 19.00 \\
Alternaria alternata & 25.00 & 16.66 & 21.15 & 20.83 & 27.77 \\
\hline
\end{tabular}

* Seed tested 200/ sample

During present investigation five seed samples of isabgol were collected from Barmer, Jalore, Jodhpur, Nagaur and Pali districts of Rajasthan during 2013-14. Examination of dry seed samples revealed the presence of deformed (shriveled), discoloured (black and brown coloured) and damaged (mechanically and insect) seeds, in addition to impurities like plant debries (pieces of leaves and stem), seeds of other crops, inert material (stones and sand) and apparently healthy seeds.

It is likely that different types of seed mycoflora during development of seeds and there storage might have caused such deformation and discoloration of seeds. Occurrence of such deformation and discoloration along with impurities have also been reported during examination of dry seeds of pearlmillet, barley and isabgol by Singh and Singh, 1983; Randhava and Aulakh, 1984 and Meena and Maharshi, 2013, respectively. For the isolation of mycoflora from isabgol seeds, two standard methods viz. Blotter and Agar Plate Methods were used to know the incidence of mycoflora. The Blotter Method displayed 5 fungi viz. Alternaria alternata, Aspergillus niger, Curvularia clavata, Curvularia fallax and Fusarium semitectum alongwith un-identified mycoflora. It also revealed that the seed sample from Jalore was infected and infested with maximum number of fungi and the sample from Jodhpur showed minimum incidence. The incidence of Alternaria alternata has been noted following standard Blotter and Agar Plate Methods. In the present study, maximum counts of A. alternata and other fungi were observed by blotter (un-sterilized and sterilized seeds) 
method as compared to agar plate (sterilized seeds) method. Other fungi detected were Aspergillus niger, Curvularia clavata, C. fallax, Fusarium semitectum and un-identified fungi. This study is in conformity to earlier findings of $[8,9,10,11,12]$ who isolated Alternaria sp., Aspergillus sp., Curvularia sp., Fusarium sp. and other fungi from seeds of isabgol.

In general, little variation was observed in blotter and agar plate methods for the presence of Alternaria alternata and other fungi recorded on seeds. Detection of $A$. alternata was higher in blotter method in comparison to agar plate method. This variation might be due to the reasons that some of the weak and slow growing fungi could not grow in agar culture in comparison to fast growing saprophytic fungi. Pre-surface sterilization of seeds and use of substratum in the method employed may be another reason [13, 14]. To have a complete spectrum of the mycoflora, it seems essential to deploy both the methods. [15] Also observed that blotter and agar plate methods are equally valuable and supplementary to each other.

\section{References}

1. Maiti, S. 2000. Cultivation of isabgol (Plantago ovata Forsk). Bulletin : National Research Centre for Medicinal and Aromatic Plants. Boriavi, Anand, Gujarat. pp. 1.

2. Mandal, K. (2010). Diseases of some important medicinal crops and their management. In : Microbial Diversity and Plant Disease Management. VDM Verlag, Dr. Muller, Germany, 509 p.

3. Anonymous, 2012-2013. Directorate of Horticulture (Statistics) 3137 laguna Street Jaipur, Rajasthan.

4. Patel, J.G., Patel, S.T. and Patel, A.J. 1984. Leaf disease of Plantago ovata in Gujarat.
Indian Phytopath. 37 : 582.

5. ISTA. 1976. International rules for seed testing. Annexure. Seed Sci. and Techno., 4:51-177.

6. Agarwal, V.K. and Sinclair,J.B.1987. Principles of Seed Pathology. CRC Press Imc. Boca, Rstom, Florida, USA.

7. Jha, D. K. 1995. Laboratory Manual on Seed Pathology. V.P.H. Pvt. Ltd. New Delhi. pp. 101.

8. Singh, T. and Singh, D. 1983. Seed borne mycoflora of sesame with special reference to Rajasthan. Indian J. Mycol. Pl. Pathol. 13: 32-42.

9. Randhawa, H.S. and Aulakh, K.S. 1984. Mycoflora associated with discoloured and shrivelled seeds of pearlmillet. Indian Phytopath. 37: 119-121.

10. Meena, M.L. and Maharshi, R.P. 2013a. Mycoflora associated with shriveled and discoloured seeds of isabgol. Environ. And Ecol., 31: 143-147.

11. Mehta, Naresh, Madan, R.L. and Thakur, D.P. 1985. Record of isabgol wilt from Haryana, Haryana Agricultural University. J. Res., 15: (4) 473-474.

12. Maharishi, R. P. 1992. Sclerotinia rot and Alternaria blight. Two new diseases of Plantago from Rajasthan. J. Mycol. Pl. Pathol. : 48 (Abstract)

13. Elwakil, M.A. and Ghoneem, K.M. 1999. Detection and location of seed borne fungi of blond psyllium and their transmission in seedlings. Pak. J. Biol. Sci. (Pakistan). 2: 38-44.

14. De Tempe, J. 1961. Routine methods for determining the healthy condition of seeds in the seed testing station. Proceeding of International Seed test. Assoc., 26:27-60.

15. Neergaard, P. and Saad, A. 1962. Seed health testing of rice, a contribution to development of laboratory routine testing methods. Indian Phytopath, 15:85-111.

\section{How to cite this article:}

Sajjan Choudhary, R.P. Ghasolia, A.L. Yadav, G.L. Kakraliya and Nasanwa, R. 2017. Detection of Seed Borne Fungi of Blonde Psyllium by Standard Blotter Methods. Int.J.Curr.Microbiol.App.Sci. 6(7): 4281-4286. doi: https://doi.org/10.20546/ijcmas.2017.607.443 